\title{
Ismail Angkat \\ STRATEGI PENANGANAN KONFLIK KEPEMIMPINAN NON-MUSLIM DI BIROKRASI \\ Studi Kasus di Kecamatan Pajangan, Bantul, Yogyakarta
}

\author{
Sekolah Tinggi Ilmu Tarbiyah Hamzah Fansuri, Aceh \\ Email: ismail_coy7@yahoo.co.id
}

Received:

2019-08-26

Received in revised form:

2019-12-17

Accepted:

2019-12-21

\section{Citation:}

Angkat, I. (2019),

Strategi Penanganan

Konflik Kepemimpinan

Non-Muslim di

Birokrasi: Studi Kasus di

Kecamatan Pajangan,

Bantul, Yogyakarta,

6(2), 232-253.

\begin{abstract}
The purpose of this research is to know the factors underlying the conflict about the Pajangan sub-district in Bantul, and how to resolution conflicts involving the Pajangan sub-district by the government and the community. The informants in this study were mass organizations, civil society, community leaders, traditional leaders, and security forces in Pajangan District related to these cases. The research used in this research is descriptive qualitative research. The results of this study reveal the facts that occurred in the Pajangan sub-district was motivated by several factors in it is the socialization of the government related to the policy of setting the Pajangan sub-district head. The government is less open to the public regarding the policies issued. The policies issued by the government are not quite right. The policy is not in accordance with the culture of the people in the Display, although the Regent's policy does not violate the laws and regulations for the election of the camat. In addition, the community also understands the Regent's policy that can consider the cultural conditions in Pajangan, especially the people in Pajangan which are full of Muslims, and also supports the differences which are the main reason for the Pajangan community to reject the camat. The government and the community have taken several actions to resolve the conflict over the conflict, such as negotiation, mediation, and finally arbitration.
\end{abstract}

Keywords: Leadership, Non-Muslim, and Bureaucracy 


\begin{abstract}
Abstrak: Tujuan penelitian ini adalah untuk mengetabui faktor-faktor apa yang melatarbelakangi terjadinya konflik penolakan camat Pajangan di Bantul, serta bagaimana resolusi konflike kasus penolakan camat Pajangan yang dilakukan oleb pemerintah dengan masyarakat. Informan dalam penelitian ini adalah ormas, civil society, tokoh masyarakat, tokoh adat, serta pihak keamanan di Kecamatan Pajangan yang mengetabui terhadap penolakan kasus tersebut. Pendekatan yang digunakan dalam penelitian ini adalah penelitian deskriptif kualitatif. Hasil penelitian ini mengungkapkan bahwa konflik yang terjadi di kecamatan Pajangan ini dilatarbelakangi oleh beberapa faktor di antaranya adalah kurangnya sosialisasi dari pemerintah terkait kebijakan dalam penetapan camat Pajangan. Pemerintah kurang terbuka terhadap masyarakat mengenai kebijakan-kebijakan yang dikeluarkannya sebingga kebijakan yang dikeluarkan oleb pemerintah kurang tepat. Kebijakan tersebut tidak sesuai dengan kultur masyarakat di Pajangan, meskipun kebijakan Bupati tidak menyalabi peraturan perundangundangan pemiliban camat. Selain itu, masyarakat merasakan kebijakan Bupati tersebut dapat mengganggu kondisi kultur di Pajangan, terutama masyarakat di Pajangan yang mayoritas muslim, serta adanya perbedaan keyakinan yang menjadi alasan utama bagi masyarakat Pajangan untuk menolak camat tersebut. Pemerintah maupun masyarakat telah melakukan beberapa tindakan sebagai resolusi konflik atas konflik tersebut, seperti negosiasi, mediasi, dan terakbir arbitrasi.
\end{abstract}

Kata Kunci : Kepemimpinan, Non-Muslim, dan Birokrasi

\title{
PENDAHULUAN
}

Seperti yang kita ketahui bahwa Indonesia yang terkenal di dunia sebagai bangsa yang menjunjung tinggi pluralisme. Terdiri dari beraneka ragam agama, bahasa, budaya, dan suku bangsa. Sehingga apa yang kita miliki dari Sabang sampai Merauke adalah berbagai macam keanekaragaman yang merupakan kekayaan dari bangsa kita. Namun dalam kehidupan berbangsa dan bernegara di Indonesia, keragaman bukan saja dilihat sebagai kekayaan oleh sebagian besar rakyat indonesia, melainkan juga sebagai suatu kekurangan dan suatu hal yang harus dihapuskan.

Situasi politik di Indonesia saat ini mengalami gelombang naik turun. Berbagai permasalahan yang sangat kompleks di dalam pemerintahan selalu menjadi sorotan dan perhatian masyarakat. Salah satu yang menjadi sorotan dalam beberapa waktu silam adalah sosok wakil gubernur DKI Jakarta yaitu Basuki Tjahaja Purnama. Salah satu isu yang menarik perhatian masyarakat Indonesia. Berkenaan dengan hal 
tersebut kasus Ahok yang terjadi pada tahun lalu dimulai saat pertemuannya dengan masyarakat Kepulauan Seribu pada tanggal 27 September 2016, mantan Gubernur petahanan ini menyinggung surat Al Maidah ayat 3. Kasus inilah yang menjadi berita terhangat pada akhir tahun 2016 bahkan hingga saat ini. Permasalahan pemimpin merupakan permasalahan yang sering disorot masyarakat. Pemilihan calon gubernur, bupati, walikota, bahkan camat menjadi ikut menjadi perhatian masyarakat, merupakan salah satu ajang pertarungan dalam memilih pemimpin di tingkat provinsi yang berlangsung setiap lima tahunan di Indonesia.

Menariknya, beberapa calon tidak hanya datang dari daerah asal pemilihan, tapi juga hadir dari luar daerah tempat pemilihan berlangsung. Pemilihan gubernur di provinsi DKI Jakarta merupakan salah satu ajang yang menarik dari berbagai kalangan, baik media, politisi, maupun mayarakat umum. Sebagai kota metropolis yang menjadi pusat perkembangan berbagai aspek, keberhasilan Pilgub di daerah ini dianggap satu ukuran keberhasilan pemilihan gubernur atau bahkan Pemilihan Umum (Pemilu) periode selanjutnya. Selain itu, keberadaan Ahok yang berlatar belakang etnis dan agama yang berbeda dari mayoritas penduduk DKI Jakarta juga menjadi sasaran penyudutan politik dari pesaing yang berlawanan. Sering kali, isu suku, agama, ras, dan antar-golongan (SARA) dijadikan sebagai isu yang menyudutkan Ahok untuk maju sebagai calon Gubernur DKI Jakarta.

Dalam konteks ini camat juga ikut menjadi perhatian masyarakat. Kecamatan dan camat dalam sejarah perjalanan Indonesia sejak kemerdekaan hingga saat ini memiliki eksitensi yang sangat penting dan unik dengan peran-peran yang disandangnya. Pengingkaran terhadap kecamatan dan camat sebenarnya merupakan sesuatu yang tidak berdasr, a-bistoris, dan perlu segera diluruskan kembali oleh pemerintah, bila hal ini dapat menimbulkan permasalahan-permasalahan yang mengganggu jalannya pemerintah dan pelayanan publik di daerah-daerah. Melihat peran terhadap eksitensi kecamatan dan camat dalam Negara Kesatuan Republik Indonesia di masa Undang-Undang No. 32 tahun 2004 yang berusaha mengungkap permasalahan-permasalahan yang dihadapi kecamatan dan camat, khususnya terkait dengan relasinya dengan pemerintahan di atas (Kabupaten/Kota, Provinsi dan Pusat)dan 
dibawahnya (desa/kelurahan). Perlu dicatat, peraturan pemerintah N0. 19 tahun 2008 tentang kecamatan (sebagai aturan pelaksana UU N0. 32 Tahun 2004), telah mengatur secara cukup rinci mengenai kecamatan dan camat. Bila kita melihat kepustakaan tentang camat dan lembaga kecamatan dapat diketahui di Indonesia ataupun di Nusantara sudah cukup lama, jauh sebelum masa kemerdekaan Indonesia. Istilah camat kiranya telah dikenal masyarakat khususnya di Jawa dan di Madura, sejak sebelum penjajahan Belanda. Di Jawa Barat terdapat istilah cutak yang peranannya sama dengan camat, yaitu seorang yang mengepalai dan membina suatu wilayah yang biasanya terdiri beberapa desa. ${ }^{1}$

Sebagai suatu organisasi yang hidup dan melayani kehidupan masyarakat yang penuh dinamika, kecamatan menghadapi banyak masalah. Kompleksitas masalah yang dihadapi berkaitan erat dengan banyaknya jumlah penduduk yang dilayani, tingkat heterogenitas (asalusul, pendidikan, umur, maupun kemampuan ekonomi), karakteristik wilayah maupun banyaknya desa/kelurahan di lingkungan kerjanya. Salah satu implikasi negatif dari penafsiran berlebihan dimaksud adalah pengubahan status, fungsi dan kedudukan kecamatan dari organisasi kewilayahan menjadi satuan keja perangkat daerah (SKPD). Berbicara tentang kedudukan kecamatan, di mana UU No. 5 tahun 1974, kecamatan merupakan wilayah administrasi pemerintah, sedangkan UU No. 22 tahun 1999, kecamatan merupakan wilayah kerja camat sebagai perangkat daerah kabupaten dan daerah kota (pasal 1 huruf m).

Dari sini terlihat betapa kuatnya posisi dan kewenangan seorang camat di wilayah kecamatan. Camat adalah kepala wilayah, wakil pemerintahan pusat, dan penguasa tunggal di wilayah kecamatan yang dapat mengambil segala tindakan yang dianggap perlu untuk menjamin kelancaran penyelenggara pemerintah. Meskipun camat adalah bawahan bupati/walikota camat mempunyai kewenangan yang cukup besar di wilayahnya. Tidak heran pada masa UU No. 5 tahun 1974, camat dapat memutuskan segala sesuatu tanpa perlu mengkonsultasikan dengan bupati. Yang perlu digaris bawahi bahwa pengangkatan camat, pada penjelasan pasal 224 UU No. 23 Th 2014 dijelaskan bahwa yang dimaksud dengan menguasai pengetahuan teknis pemerintahan adalah

${ }^{1}$ Djaja s. Meliala, Perkembangan Hukum Perdata Tentang Orang Dan Hukum Keluarga (Bandung: Nuansa Aulia, 2007). Hal. 1 
dibuktikan dengan ijazah diploma atau sarjana pemerintahan atau sertifikat profesi kepamongprajaan. Kenyataan yang berlaku sekarang ini banyak camat yang tidak memenuhi syarat dimaksud di atas.

Berdasarkan latar belakang di atas, peneliti tertarik untuk mengkaji lebih jauh mengenai Strategi Penanganan Konflik Kepemimpinan NonMuslim di Birokrasi; Studi Kasus di Kecamatan Pajangan, Bantul, Yogyakarta.

\section{METODE PENELITIAN}

Penelitian ini menggunakan jenis penelitian kualitatif. Metode kualitatif didefinisikan Creswell $^{2}$ sebagai sebuah proses penyelidikan untuk memahami masalah sosial atau masalah manusia berdasarkan pada penciptaan gambaran holistik lengkap yang dibentuk dengan kata-kata melaporkan pandangan informan secara terperinci dan disusun dalam latar ilmiah dan menggunakan pendekatan studi kasus, yang akan menghasilkan data deskriptif dan bersifat narasi. Mengapa peneliti disini menggunakan kualitatif studi kasus? Pertama pengertian pendekatan studi kasus adalah pendekatan kualitiatif yang penelitiannya mengeksplorasi kehidupan nyata, sistem terbatas kontemporer (kasus) atau beragam sistem terbatas, melalui pengumpulan data yang detail dan mendalam yang melibatkan beragam sumber informasi atau sumber informasi majemuk (misalnya,pengamatan, wawancara, bahan audiovisual, dan dokumen dan berbagai laporan) Creswell dikarenakan disini penulis melihat suatu konflik yang terjadi masyarakat dan pemerintah dalam hal ini kebijakan Bupati Bantul. Pertimbangan mengapa menggunakan metode ini adalah karena permasalahan yang ekskulsif dan sedang hangat terjadi. Selain itu penelitian ini berkenaan dengan satu fase spesifik atau khas namun tetap mempunyai kaitan dengan global. Hasil penelitian dengan pendekatan ini memberi gambaran luas dan mendalam terkait konflik penolakan Camat Pajangan.

Penelitian ini termasuk dalam kategori penelitian lapangan, yang mana peneliti terjun langsung ke lokasi penelitian untuk mencari data yang valid dan diperlukan untuk keperluan analisis dalam penelitian. Data primer yang digunakan adalah wawancara dengan narasumber yang

2 J Creswell, 'Qualitative Inquiry \& Research Design: Choosing Among Five Approaches' (California: Sage Publication, 2007). 
berkaitan langsung dengan masyarakat yang berkonflik guna mendapatkan fakta-fakta yang terperinci dan mendalam.

\section{LANDASAN TEORI}

Konflik dapat diartikan sebagai percekcokan, perselisihan, pertikaian, pertentangan, benturan, atau clash antar manusia. Konflik dapat timbul bila ada perbedaan pendapat, pandangan, nilai, cita- cita, keinginan, kebutuhan, perasaan, kepentingan, kelakuan, atau kebiasaan. Perbedaan seperti itu bisa dialami di berbagai bidang kehidupan, seperti kebudayaan, agama, politik, ekonomi-sosial, ilmu pengetahuan dan pendidikan, dunia bisnis, pemerintahan, bahkan juga dalam bidang rekreasi dan gaya hidup.

Konflik dapat terjadi pada tingkatan personal dan pada tingkatan kelompok. Konflik sosial berati konflik yang terjadi dalam kelompok dalam kehidupan sosial kemasyarakatan. Meliala menegaskan bahwa konflik sosial adalah "situasi yang mengacu pada perbedaan tujuan serta kepentingan yang tajam antar orang per orang atau cara yang dipilih oleh orang per orang dalam mengatasi perbedaan tujuan dan kepentingan". 3

Adakalanya konflik dapat diatasi dengan mengadakan komunikasi dan negoisasi yang baik. Akan tetapi, sering kali konflik-konflik tidak dapat dengan mudah diselesaikan, tidak dapat diatasi, berlarut-larut, dan bermuara kepada timbulnya kekerasan dan perilaku anarkhis. Dalam keadaan seperti itu, perlu dicari strategi khusus untuk membantu pihakpihak yang berkonflik agar konflik tersebut dapat diselesaikan dengan baik tanpa harus ada kekerasan.

Hadiati (2007:8) menyatakan bahwa konflik vertikal adalah pertentangan kelompok masyarakat dengan pemerintah. Konflik ini dapat berupa aksi mogok, boikot, unjuk rasa, kerusuhan, anarkisme dan lain sebagainya. Berdasarkan hal di atas, dapat dipahami bahwa Konflik vertikal adalah konflik yang terjadi dalam lapis kekuasaan yang berbeda, dimana yang satu memiliki kekuasaan yang lebih tinggi dari yang lainnya. Misalnya antara pemerintah daerah dengan pemerintah pusat, antara pemegang kekuasaan dengan komunitas atau kelompok masyarakat, atau antara atasan dengan bawahan. Hal ini berbeda dengan konflik horisontal

${ }^{3}$ Djaja s. Meliala, 'Perkembangan Hukum Perdata Tentang Orang Dan Hukum Keluarga' (Bandung: Nuansa Aulia, 2007). 
dimana konflik terjadi antar individu, kelompok masyarakat, atau komunitas yang satu dengan yang lain dalam lapisan yang sama.

\section{PEMBAHASAN}

\section{PAJANGAN: AWAL MULA KONFLIK}

Ketika mendengar Pajangan, banyak orang membayangkan tentang penolakan camat, kenapa ini bisa terjadi? Penolakan camat dari masyarakat langka terjadi seperti di Pajangan. Penolakkan camat di Pajangan memang tidak dapat dipungkiri bahwa pandangan masyarakat luas terhadap kecamatan Pajangan banyak ber-aura negatif. Hal tersebut merupakan suatu asumsi yang memang tidak dapat disalahkan. Karena berbagai kondisi instabilitas acapkali mengiringi kehidupan masyarakat Pajangan. Keadaan tidak kondusif yang terjadi saat ini.

Namun, dibalik pandangan banyak masyarakat terhadap kecamatan Pajangan dari sisi negatif, kita juga bisa mendapatkan berbagai macam hal positif dan banyak hal yang dimanfaatkan. Salah satu contohnya Pajangan dikenal sebagai wilayah pembatik yang produktif. Hal tersebut menjadikan Pajangan sebagai salah satu daerah tujuan utama bagi para wisatawan sejak Yogyakarta dikenal sebagai penghasil batik. Produktifnya masyarakat Pajangan tersebut merupakan salah satu faktor yang membuat Pajangan makin dikenal para wisatawan. Banyak wisatawan yang hadir di tengah masyarakat terkadang menjadi suatu kebanggaan tersendiri.

Aksi ormas FJI penolakan camat no-muslim depan Greja Pajangan

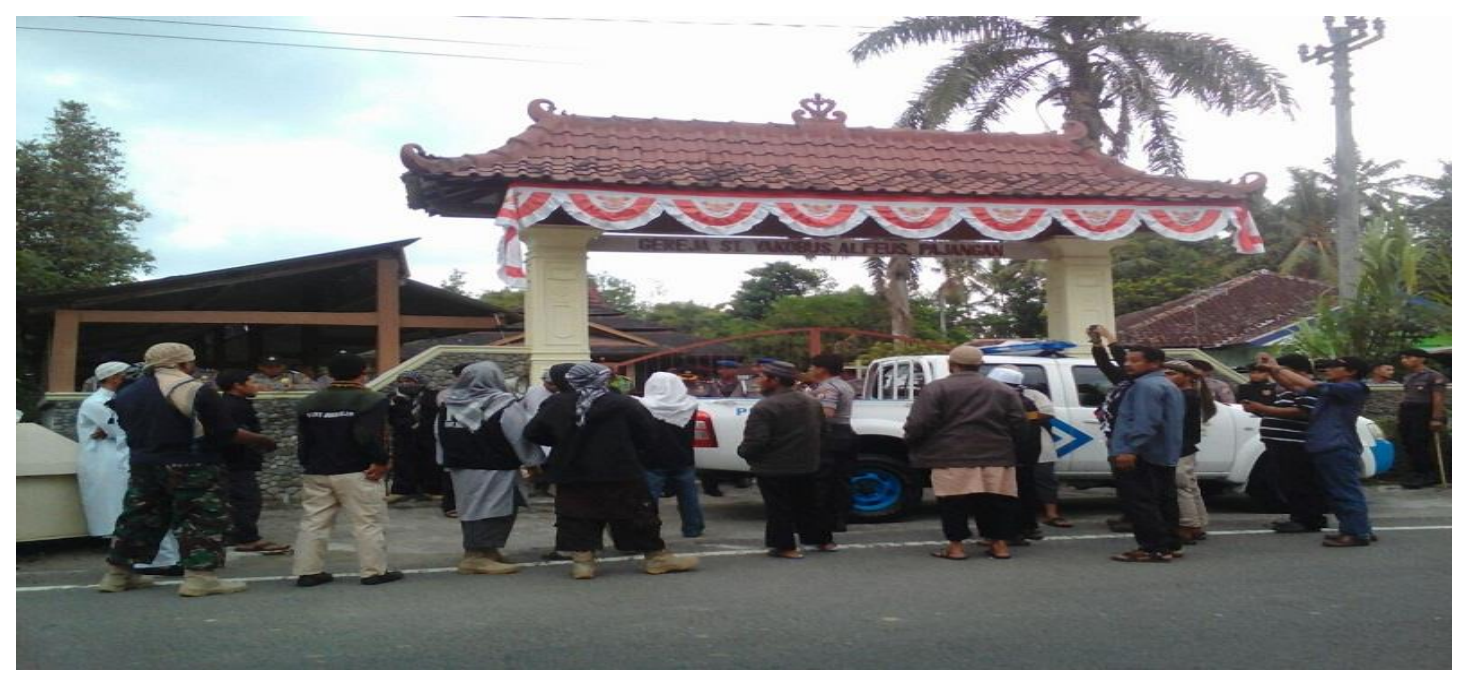




\section{Konflik yang Muncul di Kecamatan Pajangan}

Konflik telah hadir di tengah masyarakat kecamatan Pajangan, tentu dengan berbagai faktor pendorong dan berbagai macam hal yang melatar belakangi. Konflik memiliki kekhasan masing-masing. Konflik yang diangkat dalam penelitian ini memiliki kekhasan dan ciri khas masing-masing, terutama apabila ingin menyoroti terkait tipe konflik yang mendera masyarakat.

Keadaan sosial masyarakat yang ada di Kecamatan Pajangan dalam keadaan sehari-hari dapat dikatakan berjalan normal, layaknya keadaan masyarakat pada umumnya. Namun, bila dilihat dan ditelaah lebih mendalam, ada momen-momen tertentu yang membuat keadaan sosial masyrakat di Kecamatan ini berubah. Perubahan Sosial yang terlihat signifikan dan drastis adalah ketika ada penolakan Camat Pajangan, dimana terdapat penolakan yang cenderung berujung konflik yang terjadi di Pajangan. Konflik terjadi dengan berbagai alasan dan berbagai latar dari berbagai kasus konflik, kemudian muncullah berbagai analisis terhadap penyebabnya. Mulai dari faktor kebijakan, agama, budaya hingga dari masalah-masalah yang bermula kecil namun lambat laun menjadi konflik dan membawa isu-isu sensitif dan membawa dampak yang lebih besar bagi kehidupan masyarakat.

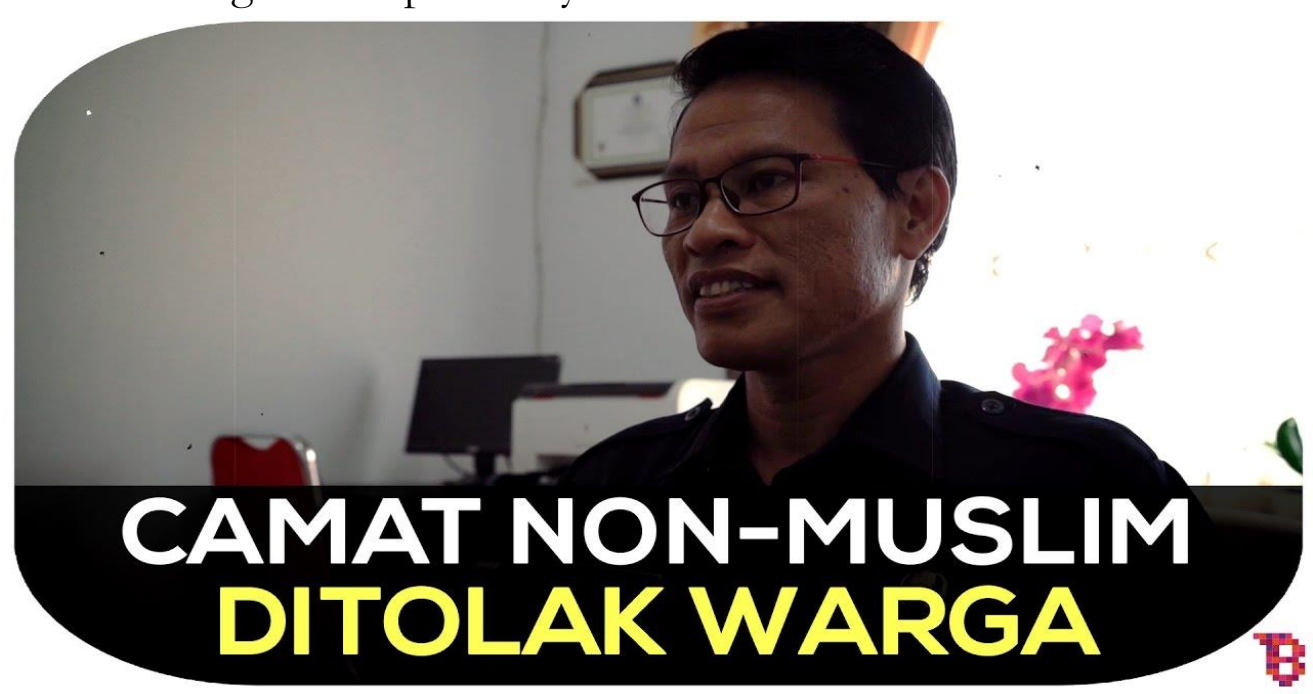

Sumber Foto: www.konflikcamatpajangan

Di akhir tahun 2016, telah tejadi protes besar-besaran oleh masyarakat pajangan. Mereka menolak atas penempatan camat yang bukan muslim, alasan mereka adalah berkaitan dengan keyakinan (believe) mayoritas di pajangan yaitu muslim. Hal ini banyak mengundang 
perdebatan teka-keti konflik ini, sesungguhnya apa yang terjadi. Karena, secara umum aksi protes masyarakat pajangan menunjukkan inteloransi antar umat beragama. Hal ini lah yang muncul di permukaan. kebijakan mutasi Bupati Bantul Suharsono menuai penolakan dari tokoh masyarakat kecamatan Pajangan menggeruduk kantor DPRD Bantul. Mereka mendesak bupati segera mengganti Camat Pajangan terlantik Yulius Suharta, Warga Pajangan mengungkapkan, masyarakat Pajangan langsung bergejolak begitu mendengar camat Pajangan diganti dengan wajah baru. Sebab, sosok camat baru ini dianggap tidak cocok dengan karakteristik masyarakat Pajangan. Masyarakat mengkritik bupati Bantul dalam mutasi camat Pajangan keliru. Yakni, tidak mempertimbangkan berbagai aspek di tengah masyarakat. Termasuk di antaranya sosiologi masyarakat Pajangan, Bupati juga tidak mempertimbangkan sejarah. Mengingat, masyarakat Pajangan beberapa tahun lalu pernah menolak keras penempatan camat baru. Sebab, sosok camat baru ini dianggap tidak mewakili karakteristik masyarakat setempat. Beberapa tahun lalu hanya 10 hari kemudian diganti. Sementara itu, anggota Komisi A Heru Sudibyo menyatakan, Komisi A tidak pernah diajak berkoordinasi terkait mutasi. Dengan adanya penolakan ini, politikus Partai Golkar ini pun mendorong bupati segera melakukan pergantian.

Mufassir, yang juga perwakilan warga, menyatakan pengangkatan Yulius sebagai Camat Pajangan telah dilakukan Bupati Suharsono. Pihaknya mengaku menolak apabila ada proses serah terima jabatan camat di Kecamatan Pajangan. (Wawancara Mei 2017)

Puluhan warga Pajangan mendatangi kantor DPRD Bantul pada 6 Januari 2017 dan menyampaikan keberatan mereka atas terpilihnya Camat Pajangan yang baru, Yulius Suharta. perwakilan warga bersama anggota DPRD Bantul dari Fraksi PKS, PPP, Golkar, PKB, PAN, dan Gerindra, mendatangi Bupati Suharsono. Sebagian besar warga Pajangan menginginkan agar Camat Pajangan yang baru diganti, dan warga meminta agar keinginan mereka disampaikan kepada Bupati Bantul. Penolakan sejumlah warga Pajangan terhadap Yulius Suharta dan dukungan fraksi-fraksi di DPRD disesalkan Ketua Fraksi PDI Perjuangan DPRD Bantul. Dia menilai peristiwa itu bisa memicu konflik dan ditiru di daerah lain. "Ini dapat mencederai kebhinekaan Indonesia. Ini namanya nasionalisme sempit. Padahal Indonesia itu berdasarkan Pancasila, Bhinneka Tunggal Ika. Saya melihatnya ini kental nuansa 
politis. Penolakan warga Pajangan terhadap pemimpin non-muslim adalah insiden intoleransi terbaru di Yogyakarta. Sebagaimana dicatat Lembaga Bantuan Hukum Yogyakarta, terjadi 13 pelanggaran kebebasan beragama dan berkeyakinan di Yogyakarta sepanjang 2011 sampai 2015. Bayu Dardias, dosen Ilmu Politik Universitas Gajah Mada (UGM), menilai insiden-insiden intoleransi di Yogyakarta menguatkan predikat provinsi itu sebagai "daerah paradoks". Pada satu sisi, menurutnya, Yogyakarta adalah basis gerakan radikal sejak era kejatuhan Presi den Suharto. Di sisi lain, sejumlah gerakan toleransi berpusat di Yogyakarta. Misalnya, Forum Kerukunan Umat Beragama dan Konsorsium Kajian Keagamaan hasil kerjasama UGM, UIN, dan Sanata Darma yang berupaya menciptakan toleransi pada ranah akademik. Peristiwaperistiwa yang terjadi akhir-akhir ini sebenarnya merupakan terusan dari sebuah proses panjang terhadap paradoks di Bantul.

"Ketua Frakasi PDI Perjuangan DPRD Bantul, Timbul Harjana, menyatakan mendukung keputusan bupati untuk. tetap menetapkan Yulius sebagai camat Pajangan. "Itu (penetapan Yulius sebagai Camat Pajangan) sudab benar, dan kami mendukung keputusan Bupati Bantul," (Wawancara Mei 2017)

Sebagaimana diungkap di depan, bahwa munculnya konflik dikarenakan adanya perbedaan dan keragaman. Berkaca dari pernyataan tersebut, Bantul adalah salah satu kabupaten dari Provinsi Yogyakarta yang berpotensi konflik. Dilihat dari berita dan media masa, konflik yang terjadi konflik vertikal. Konflik menunjuk pada konflik yang berkembang di antara anggota masyarakat dan negara yang bernuansa, suku, agama, ras, dan antara golongan seperti yang terjadi poso dan papua. Konflik vertikal konflik yang terjadi antara masyarakat dan pemerentah setempat. Umumnya konflik ini terjadi karena ketidakpuasan atas kebijakan pemerintah. Seperti konflik kebijakan pemerintah Bantul atas penetapan camat Pajangan sehingga menimbulkan gerakan-gerakan civil society.

Pimpinan Pondok Pasantren Al-Ibdad mengemukakan bahwa. Sepanjang sejarah agama dapat memberi sumbangsih positif bagi masyarakat dengan memupuk persaudaraan dan semangat kerjasama antar anggota masyarakat. Namun sisi yang lain, agama juga dapat sebagai pemicu konflik antar masyarakat beragama. Ini adalah sisi negatif dari agama dalam mempengarubi masyarakat Dan hal ini telah terjadi di beberapa tempat di Indonesia. Pada bagian ini akan diuraikan sebab terjadinya konflik 
masyarakat yang di latarbelakangi dengan agama khususnya yang terjadi di Pajangan. (Wawancara Mei 2017)

Perbedaan Doktrin dan Sikap Mental. Sebagian pihak masyarakat Pajangan yang sedang terlibat dalam protes penolakan camat Pajangan masyarakat protes dikarenakan tidak sesuai dengan keyakinan masyarakat mayoritas. Entah sadar atau tidak, setiap pihak mempunyai gambaran tentang ajaran agamanya, membandingkan dengan ajaran agama lawan, memberikan penilaian atas agama sendiri dan agama lawannya. Dalam skala penilaian yang dibuat (subyektif) nilai tertinggi selalu diberikan kepada agamanya sendiri dan agama sendiri selalu dijadikan kelompok patokan, sedangkan lawan dinilai menyalahi. Agama Islam dan Kristen di Bantul, merupakan agama samawi (revealed religion), yang diyakini terbentuk dari wahyu Ilahi Karena itu ia memiliki rasa superior, sebagai agama yang berasal dari Tuhan. Di beberapa tempat terjadinya protes dari kalangan kelompok ormas, memandang penunjukan camat tidak sesuai dengan kultur masyarakat setempat. Dengan demikian ormas menjadi wadah bagi penolakan camat dan politik di samping agama. Karena itu, faktor perbedaan doktrin dan sikap mental serta kelompok masyarakat Islam dan Kristen punya andil sebagai pemicu konflik.

Peace building dibutuhkan untuk benar-benar memutus rantai penolakan/konflik yang berulang kali terjadi. Namun, dalam peace building dibutuhkan adanya keseriusan dari semua pihak untuk menjalanakan berbagai program yang berusaha dimasukan dalam proses peace building. Karena peace building tidak hanya berpatokan pada pembangunan secara fisik saja, namun dapat dilihat lebih dalam tentang bagaimana peace building harus menyusur ke semua sektor kehidupan masyarakat? Karena rekonstruksi pasca konflik harus menyeluruh, seperti dari sisi psikologis, ekonomi, sosial, politik dan keamanan. Dengan perhatian ke semua sektor kehidupan masyarakat, keadaan damai yang abadi pasca konflik diharapkan akan terealisasi di tengah masyarakat yang akan benar-benar dapat mendapatkan keadilan dan akan menghentikan berbagai konflik yang terjadi di masyarakat.

Dapat dilihat bagaimana post conflict management sangatlah penting, terutama bagaimana menyangkut terhadap peace keeping dan peace building, karena keberhasilan mewujudkan suatu perdamaian yang abadi tidak jauh dari bagaimana menerapkan kedua aspek tersebut. Karena aspek 
terpenting adalah bagaimana menyelesaikan masalah tidak hanya sebatas berdamai secara fisik saja, namun harus dilihat bagaimana akar konflik yang akan dan bagaiamana cara menjaga perdamaian setelah perdamaian diwujudkan. Tidak berhenti sampai situ saja setelah perdamaian dijaga harusnya ada tindakan konkrit untuk membangun dari berbagai sektor kehidupan masyarakat. Diharapakan, dengan pembangunan yang merata di segala aspek kehidupan masyarakat akan menghilangkan jurang perbedaan sehingga dapat meminimalisir potensi konflik.

Dapat Dilihat bahwa berbagai konflik yang terjadi secara garis besar pasti sudah diatasi dan sudah diselesaikan dengan berbagai cara, namun, dalam keadaan masyarakat saat ini tidak hanya sebatas resolusi sementara yang dikeluarkan dan dikemukakan, tetapi, tahap lebih jauh adalah bagaimana manajemen pasca konflik yang terjadi pada tataran apakah perdamaian yang terealisasikan dapat bertahan dalam waktu yang cukup lama, setelah itu dalam tahap yang lebih jauh, untuk mendapatkan perdamaian yang abadi harus adanya peran dari semua pihak dalam mewujudkan konsep-konsep yang mengarah pada pembangunan perdamaian di semua aspek kehidupan masyarakat, sehingga perdamaian jangka panjang dapat terwujud dan terus terjaga.

Perbedaan suku dan ras pemeluk agama. Tidak dapat dipungkiri bahwa perbedaan ras dan agama memperlebar jurang permusuhan antar bangsa. Perbedaan suku dan ras ditambah dengan perbedaan agama menjadi penyebab lebih kuat untuk menimbulkan perpecahan antar kelompok dalam masyarakat. Contoh di kecamatan Pajangan, Bantul, sebagian masyarakat menolak camat karena perbedaan agamanya. Di beberapa tempat di Indonesia yang terjadi kerusuhan seperti: Poso, Tolikara, dan Singkil, massa yang mengamuk adalah penduduk setempat. Sedangkan yang menjadi korban keganasan massa adalah yang umumnya berbedaan dengan agama mayoritas. Jadi, nampaknya perbedaan kultur dan suku disertai perbedaan agama ikut memicu terjadinya konflik.

Perbedaan Tingkat Kebudayaan. Agama sebagai bagian dari budaya bangsa manusia. Kenyataan membuktikan perbedaan budaya berbagai bangsa di dunia tidak sama. Secara sederhana dapat dibedakan dua kategori budaya dalam masyarakat, yakni budaya tradisional dan budaya modern. Tempat-tempat terjadinya konflik antar kelompok masyarakat Pajangan, beberapa waktu lalu, nampak perbedaan antara dua kelompok yang konflik itu. Kelompok masyarakat setempat memiliki 
agama mayoritas yaitu muslim. Sedangkan yang menjadi lawan dari masyarkat adalah negara, dimana negara mengambil kebijkana tidak melihat kondisi sosial masyarakat Pajangan.

Keadan konflik yang begitu menyedot perhatian berbagai kalangan disebabkan oleh adanya keterlibatan aktor politik. Aktor politik yang berasal dari kalangan partai Nasional. Mobilisasi massa yang digunakan banyak pihak guna menambah amunisi sangat disayangkan, karena aktoraktor dari partai dan kelompok yang ikut andil mayoritas memberikan bantuan tanpa tahu masalah yang sebenarnya terjadi, dan tanpa memikirkan konsekuensi apa yang akan ditimbulkan kedepannya. Faktorfaktor tersebut menjadi titik terpenting dalam proses eskalasi dalam sebuah konflik. Permasalahan yang awalnya hanya sebatas penolakan camat, berkembang menjadi konflik besar yang melibatkan isu etnisitas dan agama. Konflik merupakan sebuah fenomena sosial yang tidak terbentuk secara spontan namun ledakan konflik terjadi karena timbunan permasalahan yang tidak terselesaikan dengan baik. Kesenjangan sosial, kegagalan membangun pola komunikasi yang baik antar masyarakat, ketidak mampuan elit lokal dalam manajemen konflik, hingga karakterkarakter yang saling berbeda dalam masyarakat menjadi element penting dalam menciptakan konflik sosial yang besar dalam masyarakat, atau yang dalam perspektif Jackues Bertrand disebut sebagai aspek konstruktifis dan primordialisme.

Secara garis besar, sejarah konflik terjadi di Kecamatan Pajangan dapat dikategorisasikan menjadi beberapa penyebab besar, yang pertama adalah, terkait penyebab kultural, seperti perselisihan perbedaan agama, ras, kebijakan dan lain-lain, kemudian terkait, antara masyarakat melawan negara, ataupun masyrakat melawan coorporate tertentu.

Catatan konflik yang dijelaskan diatas hanya konflik masyarakat dengan negara di Kecamatan Pajangan, terutama konflik yang cukup mendapat perhatian dari masyarakat luas, sehingga dampak yang dihasilkan cukup luas dan menarik perhatian publik lokal maupun nasional. Sehingga berdampak kecil atau besar merubah keadaan sosial politik lokal hingga nasional. Sejarah kelam tentang konflik yang terjadi di Kecamatan Pajangan, tidak dipungkiri akan membawa dampak pada kehidupan yang akan datang, karena sejarah yang ada tidak dapat serta merta dihilangkan dari kehidupan masyarakat kedepannya. Dapat 
dipastikan sejarah akan membentuk kehidupan sosial politik di kemudian hari.

Sumber Foto: www.konflikcamatpajangan

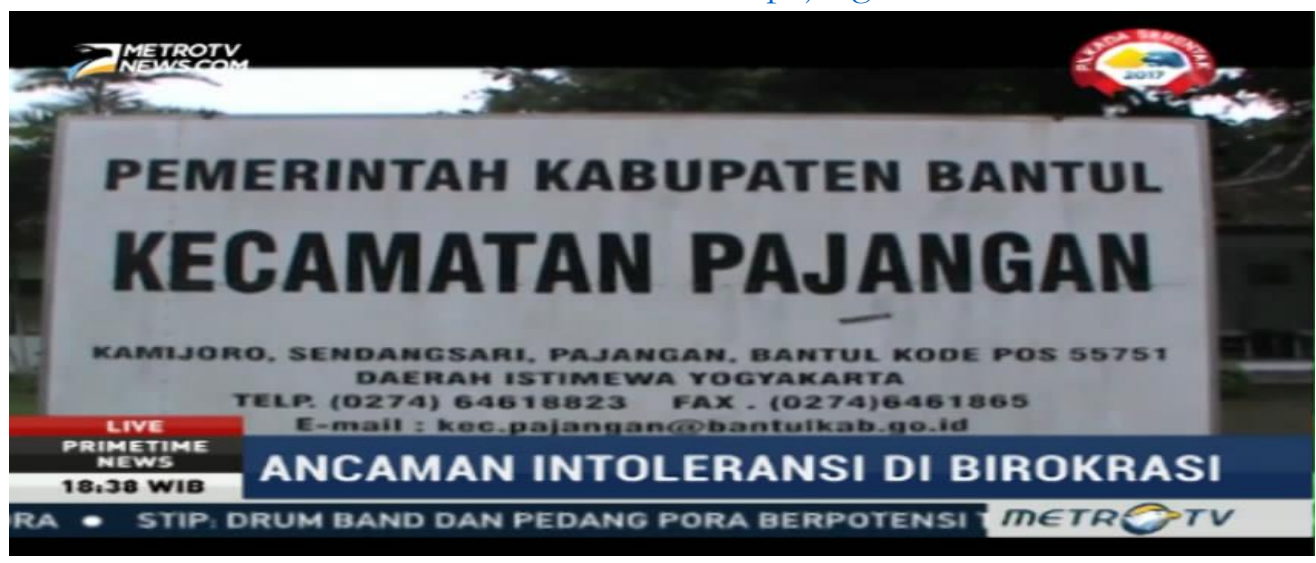

\section{Konflik Vertikal Pajangan}

Yang pertama disoroti adalah terkait konflik kecamatan Pajangan yang terjadi di tahun 2016 akhir. Konflik yang terjadi antara negara dalam hal ini, aparat pemerintahan berhadapan dengan warga yang menolak camat Pajangan dari ketentuan yang telah diatur dan diperbolehkan di Indonesia. Atas dasar penolakan camat tersebut tindakan represif dilakukan oleh warga dalam hal ini masyarakat Pajangan melakukan demo dengan dalih ingin membatasi agar masyarakat Pajangan tidak dipimpin oleh camat yang non muslim, yang kemungkinan kedepannya akan menimbulkan masalah di tengah masyarakat. Tindakan yang dilakukan oleh pihak masyarakat merupakan tindakan persuasif. Upaya persuasive yang dilakukan pemerintah justru tidak mendapat tanggapan. Sehingga upaya demo akhirnya digunakan sebagai langkah akhir dalam penolakan tersebut.

"Menurut Temu Panggih Raharjo, perwakilan warga Pajangan mengatakan babwa penetapan Yulius sebagai Camat Pajangan tak sesuai dengan karakter dan kondisi psikologis warga. Pasalmya di daerah Pajangan pernah terjadi peristiwa pelarangan pendirian patung di sebuah gereja di wilayah Pajangan pada Oktober 2016. Masyarakat masih terluka dengan masalah lama. Masyarakat yang belum paham, (permasalahan) terbawa, seperti ada SARA," ujarnya di Kantor Bupati Bantul, Yogyakarta, (Wawancara Januari 2017) 
Isu terkait agama memang sangat sensitif di era Orde Baru, terutama bila dilihat dari sisi historis yang ada. Masyarakat Pajangan diyakini sebagai kelompok Islam Moderat yang dipercayai kedepannya akan dapat menjaga kestabilan Kecamatan Pajangan. Pergolakan antara warga masyarakat dan pemerintah merupakan ketegangan yang bersifat vertical, dimana masyarakat yang dianggap melawan kebijakan Pemerintah Bantul.

Bupati Bantul menegaskan bahwa pengisian jabatan tidak melihat agama, namun berdasarkan kinerja dari yang bersangkutan. Keberadaan Camat Pajangan justru untuk mempererat keberagaman, memperteguh kebhinekaan yang ada di Kecamatan Pajangan," Suharsono menyatakan tak akan mengganti atau memindabkan Camat Julius sebelum mengetahui secara pasti dan benar permasalaban di masyarakat Pajangan. (Wawancara Mei 2017)

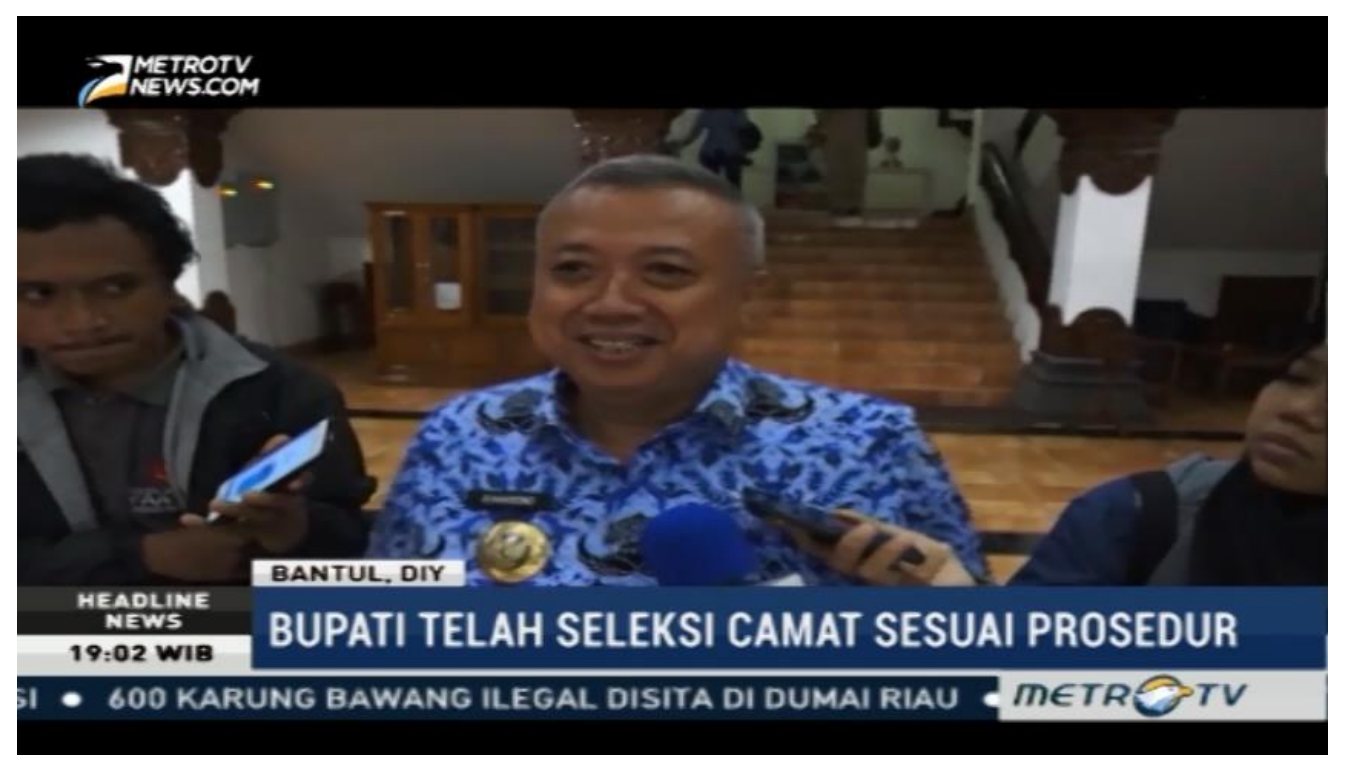

Berbagai alasan dikemukakan oleh masyarakat Pajangan, tentu dengan dalih pembenaran dengan apa yang mereka lakukan. Masyarakat dan pemerintah menjadi korban dari peristiwa ini menurut laporan dari Tribun Jogja (2016), hasil dari perlakuan represif yang dilakukan oleh pemerintah, karena ketika ada upaya-upaya melawan ataupun bertolak belakang dengan apa yang sudah di atur oleh Negara, maka akan dengan mudah Negara menyelesaikan hal tersebut, tentu dengan dalih yang mereka anggap benar-benar.

Konteks kasus Kecamatan Pajangan yang terkenal dengan pemerintahan yang sangat kuat, terutama bicara masalah kekuatan 
keamanannya yang ditopang oleh TNI ataupun POLRES setempat. Pemerintah dengan penuh di back up oleh aparat. Sehingga apabila ada konflik yang bersifat vertikal dapat dipastikan negara akan lebih superior, dan secara otomatis masyarakat akan menjadi inferior. Kadangkala tidak penting untuk dipikirkan pihak masyarakat yang salah atau benar? Ketika negara sudah maju dalam proses penanganan, apapun yang mereka lakukan akan dibenarkan oleh negara, walaupun harus dengan melakukan tindakan kekerasan terhadap warganya sendiri. Karena ketika mereka mengganggap ada sedikit penyimpangan, maka apa yang mereka pandang benar akan dibenarkan. Walaupun ketika harus berakhir di meja hijau, pandangan pemerintah pasti akan dianggap paling benar.

\section{PROSES PENYELESAIAN KONFLIK (MUSYAWARAH)}

Setiap munculnya konflik selalu mengalami eskalasi hingga deskalasi (pasang surut) keadaan yang terjadi. Menurut pihak-pihak terkait setiap permasalahan harus segera diselesaikan. Tujuan dari permasalah ini adalah tidak lagi terjadi timbunan permasalahan yang mengakibatkan konflik semakin membesar dan dapat mengakibatkan korban jiwa maupun materi. Oleh karena itu, beberapa konflik yang pernah mendera Kecamatan Pajangan telah berada pada proses yang baik dalam menyelesaikan sebuah konflik.

Kemudian untuk menindaklanjuti hal tersebut, perwakilan dari pemerintah memiliki inisiatif untuk datang ke Kecamatan Pajangan melakukan jemput bola, agar kesimpangsiuran di tengah masyarakat cepat terselesaikan. Dalam hal ini Camat, Kapolsek hingga Danramil pun dilibatkan dalam usaha pertama untuk mengklarifikasi kegiatan apa yang kelompok ini lakukan, karena banyak laporan yang menganggap ada kegiatan melenceng dari apa yang dilakukan oleh kelompok ini yang tidak seperti syarat Islam umumnya. Berbagai kecurigaan yang berindikasi pada adanya niatan dari kelompok ini untuk merubah dasar Negara menjadi Syariat Islam. Niatan awal yang cukup baik untuk menyelesaikan masalah dengan cara negosiasi pun batal dijalankan karena ada penolakan dari pihak kelompok masyarakat. Bahkan dalam prosesnya awal negosiasi yang gagal dan adanya perlawanan dari kelompok masyarakat. Karena perlawanan yang dilakukan kelompok tersebut tidak dalam perkiraan pemerintah. 
Kemudian dalam konflik yang melibatkan Kecamatan Pajangan dan Negara, proses mewujudkan perdamaian dalam konflik vertikal ini diperankan aktif oleh para tokoh ormas setempat, tokoh masyarakat, tokoh agama yang merupakan unsur dari masyarakat. Sedangkan unsur pemerintahan menghadirkan Bupati, Sekretaris Daerah, dan anggota DPR juga hadir, dalam forum rapat guna merumuskan perwujudan perdamaian antar masyarakat Pajangan dan Negara. Kami akan menyerahkan sepenuhnya permasalahan yang terjadi untuk diproses sesuai dengan aturan yang berlaku.

1. Kami akan selalu menjaga persatuan dan kesatuan.

2. Kami tidak akan membeda-bedakan suku, golongan, dan agama

3. Kami akan selalu menjaga keamanan dan keyamanan Kecamatan kami.

4. Kami sepakat bahwa di masa yang akan datang kami tidak akan melakukan aksi main hakim sendiri terhadap tindakan kriminal yang terjadi di Kecamatan kami masing-masing dan akan kami serahkan sepenuhnya kepada pemerintah dan tokoh masyarakat Pajangan.

Lebih jelas lagi bukti kesepakatan damai yang disepakati oleh kedua belah pihak dan disaksikan oleh pihak yang berwajib, banyak point penting yang menjadi titik paling penting dalam melihat interaksi masyarakat dan pemerintah kedepannya. Oleh karena itu, perlu adanya peran peran lebih besar dari berbagai pihak guna untuk memberikan dorongan, bimbingan maupun pengawasan terutama dari pihak-pihak yang menjadi saksi-saksi ataupun yang paling berperan dan memiliki pengaruh dalam proses perjanjian yang yang telah disepakati. Maka dari itu, selanjutnya akan dibahas lebih rinci bagaimana masing-masing peran perorangan atau institusi dalam proses konflik, mulai dari konflik muncul hingga perjanjian terealisasikan, kemudian juga tidak melupakan aktoraktor aktor-aktor setelah proses perdamaian dilakukan, khususnya dalam proses menjaga perdamaian dikemudian hari, hingga tahap pembangunan perdamaian dilaksanakan.

Proses panjang hingga mencapai suati kesepakatan damai dengan 5 poin perjanjian tertulis mengalami pasang surut dan tarik ulur yang dilakukan oleh banyak pihak, sehingga apapun yang dihasilkan dalam perjanjian tersebut merupakan suatu intisari dari apa yang telah menyebabkan suatu konflik dapat terjadi dan dirasa perjanjian tersebut dikemudian hari tidak akan timbul lagi dipermukaan. Meskipun terdapat 
berbagai perdebatanyang cukup alot dan sengit, tapi disini dapat dilihat dalam suatu keadaan panas masih ada itikat baik dari semua masyarakat yang ikut ambil bagian pada proses perdamaian, mereka mengedepankan budaya musyawarah untuk segera merealisasikan perdamaian yang dituntut untuk segera terwujud, namun, disamping itu segala macam yang dibuat harus tetap mengacu pada semua kepentingan masyarakat, tidak hanya salah satu pihak saja yang merasa diuntungkan. Proses perdamaian, hingga pasca konflik terjadi, membutuhkan kerja keras dari banyak pihak, namun perlu dicermati segala usaha dan daya juang guna mewujudkan perdamaian juga harus dilihat dari berbagai aspek, salah satunya adalah melihat dari aspek nilai-nilai kultural yang dimiliki oleh masing-masing kelompok masyarakat. Dalam konteks penelitian ini menemukan perwujudan perdamaian dari konflik Kecamatan Pajangan ini menggunakan perspektif nilai-nilai luhur kebudayaan dan kondisi masyarakat setempat. Sehingga musyawarah yang memang pada tujuan awalnya sebagai wadah untuk masyarakat menyalurkan segala macam keluhannya dapat diterima dan diakomodasi dalam suatu perjanjian damai.

Perjanjian yang telah terwujud dengan mengacu pada berbagai aspek kehidupan masyarakat, diharapkan kedepannya akan menjadi suatu acuan apabila terdapat friksi-friksi yang melibatkan Kecamatan Pajangan, karena diharapkan setelah ini akan terwujud suatu hubungan yang baik. Hubungan yang erat akan menjadikan hubungan dari kelompok masyarakat dan pemerintah yang berseteru akan semakin membaik. Oleh karena itu, dalam konflik yang terjadi di Kecamatan Pajangan. Diharapkan kedepannya akan membawa dampak positif, selain kerugian yang telah dialami pada saat konflik terjadi, saat ini coba melihat dari sisi yang berbeda, masyarakat akan berusaha merubah hal yang besar, dari hal konflik yang sebelumnya bersifat merugikan masyarakat ditransformasikan ke arah yang positif. Seperti apa yang dikatakan Lewis Conser bahwa konflik mengarah ke perubahan, tapi juga bisa positif bagi kelompok. Konsekuensi positif konflik meliputi menetapkan karakter masyarakat, menetapkan identitas masyarakat, mempertahankan stabilitas dan meningkatkan kohensif (kerekatan) masyarakat.

Pasca terealisasinya ikrar perjanjian damai masyarakat Pajangan dan Pemerintah yang didasarkan pada banyak aspek terkait agar kejadian tersebut tidak terulang lagi. Penyelesaian konflik yang mengedepankan 
musyawarah dan dengan tidak melupakan masalah pokok yang menjadi penyebab terkait adanya masalah kriminalitas. Dengan adanya musyawarah yang dilakukan berbagai pihak dan pada akhirnya melahirkan point-point kesepakatan. Pada dasarnya awal musyawarah yang dilakukan tidak berbeda jauh dengan pedoman penyelesaian konflik melewati jalur non litigasi penyelesaian konflik, dengan cara ini mengedepankan penyelesaian konflik tanpa menggunakan jalur peradilan. Kenyataannya, salah satu usaha dilakukan untuk merealisasikan perdamaian dengan cara mengedepankan nilai-nilai lokal yang ada di tengah masyarakat.

Proses yang hampir salam dalam konteks konflik yang melibatkan Kecamatan Pajangan. Dimana proses perjanjian damai melalui negosiasi antar beberapa pihak menghasilkan point-point perjanjian damai yang disepakati bersama antar masyarakat Pajangan dan Pemerintah setempat. Walaupun akhirnya perjanjian damai terealisasi, proses yang dilakukan cenderung cukup lama dan berbelit-belit, butuh waktu lebih lama dari tiga bulan, sehingga segala kerugian yang disebabkan oleh konflik akan segra mungki hilang.

\section{PENUTUP}

Berdasarkan uraian data-data dan berbagai analisis yang dilakukan guna menjawab pertanyaan penelitian terkait manajemen pasca konflik sosial yang ada di Pajangan, terutama terkait bagaimana mewujudkan perdamaian jangka panjang di kecamatan Pajangan. Untuk menguak dan menganalisis berbagai kejadian dan persoalan yang terjadi antara masyarakat dan pemerintah,

Konflik vertikal yang terjadi saat ini lebih mudah muncul dipermukaan, dengan dinamika konflik yang dinamis, dalam kurun waktu yang cukup singkat terjadi pasang surut keadaan yang terjadi. Dinamika konflik terus berlangsung di tengah masyarakat, dengan hal tersebut suasana mencekam tidak dapat dihindarkan. Ditambah dengan adanya upaya mobilisasi masa dari aktor-aktor luar grup yang sesungguhnya tidak memiliki kepentingan dalam konflik yang terjadi, membuat suasana semakin keruh. Ketika trigger konflik tidak dapat segera diatasi, masalah lain akan dengan cepat membuntuti dibelakangnya seperti adanya mobilizing factors (faktor yang memobilisasi) dari pihak luar. Terbukti banyak pihak yang berasal dari 
luar kecamatan ikut ambil bagian dalam konflik tersebut, dengan berbagai alasan yang melatarbelakangi dengan kepentingan dan tujuan masing-masing. Hal tersebut terus bergulir dan muncul masalah tambahan seperti aggravating factor (faktor yang memperburuk). Terbukti dengan adanya aksi demo ke kantor DPRD

Terwujudnya perdamaian dalam tata kelola konflik sosial pada konteks konflik di Kecamatan Pajangan, terlihat dari apa yang telah disepakati oleh pihak-pihak yang berkonflik. Perjanjian damai merupakan salah satu perwujudan dari peace making. Ketika perjanjian damai telah disepakati, dapat dipastikan bahwa salah satu tahap krusial dalam mewujudkan perdamaian negatif telah terwujud. Dalam proses mewujudkan perdamaian dalam konflik di Pajagngan tidak semudah membalikan telapak tangan, banyak proses yang harus dilalui. Secara umum dalam mewujudkan perdamaian konflik di Pajangan, para pihakpihak tersebut melalui tahap yaitu, non litigasi (negosiasi dan mediasi), rekonsiliasi dan coercive. Tahap negosiasi merupakan tahap awal yang digagas untuk sesegera mungkin mewujudkan perdamaian, tahap ini murni diprakarsaai oleh tokoh masyarakat Bantul dan hanya dihadiri oleh perwakilan perangkat daerah, dan ditambah beberapa warga. Dalam proses ini belum efektif untuk mewujudkan perdamaian.

\section{Saran}

Dari serangkaian anlisis terhadap manajemen pasca konflik yang telah dilakukan di Kecamatan Pajangan. Penulis dapat memberikan saran pada tataran praktis terutama pada Pemerintah Kabupaten Bantul. Konflik yang terjadi di Pajangan seharusnya menjadi pelajaran berharga kedepannya terutama bagaimana langkah antisipatif sebelum munculnya konflik dipermukaan. Karena selama ini, konflik yang muncul seharusnya tidak sampai membesar dan dapat dicegah. Peranperan intelejen daerah seharusnya dimaksimalkan masuk kedalam jejaring kehidupan masyarakat, sehingga potensi konflik dapat diredam terlebih dahulu.

Terkait perdamaian yang telah terwujud antara desa masyarakat dan pemerintah, dapat dijaga keberlangsungannya, dengan cara mengutamakan koordinasi yang terus dibangun antara semua pihak. Mulai dari stakeholders pemerintahan yang terus bersinergi dan tidak lupa untuk tetap memaksimalkan peran masyarakat, karena selama ini, 
peran masyarakat tidak dimaksimalkan dalam proses manajemen pasca konflik. Karena melihat pentingnya sinergitas dari semua pihak dalam proses menjaga perdamaian yang diharapkan akan selalu langgeng dalam jangka waktu yang panjang.

Dalam tataran teoritik, masih banyak celah yang dapat dilihat karena keterbatasan akses yang didapat peneliti. Hal tersebut merupakan peluang untuk para peneliti kedepannya yang ingin konsen terhadap berbagai masalah konflik, terutama pada tahap pasca konflik terjadi. Limitasi tersebut dapat menjadi acuan ketika terkait peluang adanya penggunaan nilai lokal yang dapat dimaksimalkan dalam manajemen pasca konflik. Kemudian, penelitian selanjutnya dapat intensif terhadap kajian berbagai kebijakan yang mendorong proses perwujudan perdamaian jangka panjang. Terutama mengkaji bagaimana efektifitas penerapan kebijakan dalam masyarakat, karena dalam rentang waktu selama satu tahun pasca konflik terjadi, ada keterbatasan dan kesan terburu-buru apabila ingin menilai keberhasilan atau kegagalan dari sebuah program yang dicanangkan dalam jangka waktu yang panjang.

\section{DAFTAR PUSTAKA}

Anthony, Giddens, \& David Held, Perdebatan Klasik dan Kontemporer mengenai kelompok, kekuasaan, kelompok, dan konflik: Teori Sosial Kontemporer (Jakarta : CV Rajawali, 1982)

Artikel Ilmiah : Kata kunci: Kedaulatan, Prinsip Non-Intervention, Humanitarian Intervention, Resolusi DK PBB, HAM. Keterlibatan North Atlantic Treaty Organization (Nato) Dalam Penyelesaian Konflik NonInternasional Di Libya Ketika Penggulingan Presiden Muammar Kaddafit erjadinya suatu Konflik.

Budiarjo, Miriam, Dasar-dasar ilmu politik (Jakarta : PT Gramedia Pustaka Utama, 2008)

Coser, Lewis A., The Function of Social Conflict (New York: The Free Press, 1956)

Creswell, J, Qualitative Inquiry \& Research Design: Choosing Among Five Approaches (California: Sage Publication, 2007) 
Fisher, Simon, dkk., Mengelola Konflik: Ketrampilan \& Strategi Untuk Bertindak (Jakarta: The British Council, 2001)

Fur Further Details, See James E. Dougherty and Robert L. Pfalt:graff Jr. Contending The ories of Internasional Relations (New York: Longman, 1996)

Jensen, Liyod, Eksplaining Foreign Policy Englewood Cliffs, Chapter 3 (NJ : Prentice Hall 1982)

Koetjaraningrat, Metode-Metode Penelitian Masyarakat (Jakarta: Gramedia, 1982)

Meliala, Djaja s., Perkembangan Hukum Perdata Tentang Orang Dan Hukum Keluarga (Bandung: Nuansa Aulia, 2007)

Murdiyanto, Eko, Sosiologi Pedesaan Pengantar Untuk Memahami Masyarakat Desa (Yogyakarta: Wisma Press UPN Veteran, 2008)

Muryanto Febriana, 'Faktor Penyebab Konflik dan Brajamusti Dalam Pesepakbola di daerah Yogyakarta' Tesis (Yogyakarta: Jurusan Pendidikan Sosiologi, UNY, Yogyakarta, 2011)

S, Iskandar, Konflik dalam Masyarakat Majemuk (Malang: Universitas Negeri Malang Press, 2006)

Suwondo, Kutut, Civil Society Di Aras Lokal (Salatiga: Pustaka Percik 2005) 